[PREPRINT]

\title{
Confucianism and Totalitarianism: An Arendtian Reconsideration of Mencius vs. Xunzi
}

\author{
Lee Wilson \\ Department of Philosophy, The University of Edinburgh \\ lee.w@.ed.ac.uk
}

\begin{abstract}
Totalitarianism is perhaps unanimously regarded as one of the greatest political evils of the last century and has been the grounds for much of Anglo-American political theory since. Confucianism, meanwhile, has been gaining credibility in the past decades among sympathizers of democratic theory in spite of criticisms of it being anti-democratic or authoritarian.

I consider how certain key concepts in the classical Confucian texts of the Mencius and the Xunzi might or might not be appropriated for 'legitimising' totalitarian regimes. Under an Arendtian approach to understanding totalitarianism, it is precisely an unproblematised relation to a normative History and Nature that underlies the potential compatibility or incompatibility. I argue against a longstanding prejudice that if any form of Confucianism would be totalitarian, it would have to be Xunzian. Against this, I hope to show that if any form of Confucianism would be totalitarian, it might well be a naturalistic Mencian Confucianism instead of a constructivist Xunzian one.
\end{abstract}

Totalitarianism is one of the greatest political evils of the last century and has been the chief foil of Anglo-European political philosophy, motivating much of it since World War II (e.g. Arendt 1968, Rawls 1996). Political philosophy in this vein has recently turned to reconstructing or drawing from Confucianism for contemporary political climates (especially with pro-democratic societies--e.g. Hong Kong, Singapore, Taiwan--that also have strong Confucian cultures; e.g. Tan 2004, Bai 2014, Chan 2014, Bell 2015). However, there remains an important yet hitherto neglected concern about whether Confucianism, qua political philosophy, is compatible with--or even supportive of--totalitarianism. After all, scholars have suggested that "Chinese culture (or tradition) has long fostered totalitarian rules" (Chen and Deng 1995, 2), often claiming this to be because "Confucianism is culturally 'totalistic' in nature" (Guo 2013, 50). ${ }^{1}$ If these claims were grounded in an actual theoretical compatibility endemic to Confucian political systems, this should raise a red flag for reconstructive attempts.

I hope to begin addressing this worry with a close consideration here, by way of Hannah Arendt, of arguably totalitarian-appropriable, yet central, elements of Confucianism--elements which have been conceptualised in different ways in the Mencius and the Xunzi.2 This concerns phenomenological aspects of the social order Arendt distinguishes as 'totalitarian,' attending to how Mencius' version of the Confucian tradition is susceptible to alignment with them, whereas Xunzi's version is not--or is at least less so. I focus here on how their different articulations of the central

\footnotetext{
${ }^{1}$ Arendt herself raises, but does not answer, the question of whether China under Mao is totalitarian (1976, xxviii; cf. Baehr 2010).

2 Accusers have understood the term 'totalitarianism' in various ways (e.g. Guo 2013), but I adopt here only Arendt's approach to the phenomenon, which has been the most influential (for alternatives, see, e.g., Sondrol 1991).
} 
Confucian concepts of ren [仁, 'benevolence' or 'humaneness'], rituals [ $l i$ 禮], and the rectification of names [zhengming 正名] might or might not be appropriated for 'legitimising' totalitarianism. ${ }^{3}$

By approaching totalitarianism with an Arendtian framework, I argue here against a longstanding prejudice that simply assumes that if any form of Confucianism would be appropriated by totalitarianism, it would likely be Xunzian (e.g. Huang 2001, Stalnaker 2015). This prejudice has been thought to arise from Xunzi's heavier emphasis on rituals, embrace of Legalist ideas, and his anticipation of Han Feizi and the Qin Empire (e.g. Hansen 2000, Tao 2006). Yet against this, I hope to show that it is Mencian Confucianism that would be more susceptible to totalitarian appropriation than a Xunzian one. This would be due to the former's characteristic commitment to a naturalistic conception of political legitimacy--for it is this commitment that would make Confucianism more vulnerable to totalitarian appropriation. 'Naturalism' is meant here in the sense of a "philosophical orientation that seeks the source of normativity in the natural realm [emphasis added]," not a more general sense of explaining phenomena in terms of natural elements or employing methods from the natural sciences (Lee 2005, 2). This may be characterised as 'naturalism about normativity', versus 'metaphysical' or 'methodological' naturalisms. Xunzi may be 'naturalistic' in these latter senses but the concern here is only for naturalism about normativity. ${ }^{4}$

For this paper, I am interested in compatibility in the weaker sense of the plausible appropriability of Confucianism for grounding totalitarianism's denial of freedom and its ersatz legitimacy. That is, in order to provide maximal interpretive charity to those who would accuse Confucianism of being totalitarian, I only attend to the weaker claim of how Mencian and Xunzian versions of Confucianism might be appropriated, rather than any stronger notion of compatibility such as employability. Yet, though appropriated, the concepts would nevertheless be characteristically Confucian (here, Mencian). Analogously, just as Nazi Germany did not so much employ Nietzsche's philosophy as appropriated it, contemporary reconstructions of a Nietzschean political system must pay heed to what makes characteristically Nietzschean concepts susceptible to totalitarian appropriation (cf. Golomb and Wistrich 2002).

To be clear, whether Mencius is generally a better source for political philosophy or whether Xunzi is more prone to authoritarianism are not concerns here. ${ }^{5}$ Further, the argument does not entail that a Xunzian brand of authoritarianism would be choice-worthy, only that there are two different ways in which Confucian (better: Confucianism-inspired) political systems may be illegitimate, with each requiring different sorts of criticisms and strategies of resistance.

\section{An Arendtian Framework}

A central puzzle for understanding totalitarianism is how, despite compromising freedom and normative legitimacy, it still possesses putative legitimacy for contributory participants. One way to characterise Arendt's approach to this would be as a phenomenology of human activity undermined by, and yet grounding, totalitarian elements of terror and ideology.

For Arendt, human activity (vita activa) involves a phenomenological triad of labour, work, and action (Arendt 1998). Labour, the dimension with the human being understood as animal laborans,

\footnotetext{
3 I leave ren [仁] untranslated to emphasise its association with ren [人] as 'human'.

${ }^{4}$ E.g. John Bethrong refers to Xunzi as propounding "non-reductive naturalism" in the metaphysical sense (Bethrong 2016, 348).
}

5 For a discussion on Xunzi as appropriable for authoritative but non-authoritarian Confucian government, see Tan 2010. 
corresponds to the necessary processes needed to sustain biological life as a species--the products of which are consumed as part of the processes. Work, with the human being understood as homo faber, corresponds to our relation to the artificial world through our production of interrelated artefacts and engagement with them--the products of which have permanence outside of the activity and give rise to a common world. Action, with the human being understood as a zoon logon ekhon, corresponds to our relations to other human beings, disclosing ourselves through speech and action, unmediated by things (as 'whos' and not 'whats', e.g. Duke Ling to Mi Zixia and not a ruler to a courtier)--the products of which are political communities. Because work and action are free from the bare necessities of animal survival, these are considered dimensions of freedom, inasmuch as an individual is free from biological demands. And as dimensions of freedom, their stability is not passively guaranteed by nature even though they supervene on them.

Importantly, a political community consists in the interrelational network of individuals as they manifest in speech and action. In this network, human beings act and understand themselves with reference to the demands governing the activity, that themselves issue from the founding event wherein the community is initially formed--by a plurality of individuals relating to each other on the basis of self-presentations unencumbered by the demands of work or labour (hence being obliged by freedom rather than power or persuasion). The internal stability of this network of individuals is a result of the persistence of the materiality and organisation of speech and action in the narratives of these presentations, which are maintained by feedback loops between the zoon logon ekhon and their narratives (Arendt 1998, cf. Thiele 2009). The standards and models that govern a world of action, then, would have the relevant normativity (e.g. the laws governing a particular state) inasmuch as they induce the participation of its individual actors sans coercion and persuasion within the community (Arendt calls this 'authority'); relate a participant back to the community's founding event ('religion'); and are seen as the standards and models encoding the testimony of those who witnessed and created the founding event, even if later augmented by recognised representatives ('tradition').

For Arendt, this conceptual triad of authority, religion, and tradition is not only compatible with, but constitutes, political legitimacy: it confers normative stability upon the free relations among a plurality of individual human beings in a political community (Arendt 1968). ${ }^{6}$ And while she is concerned with the loss of this triad in Anglo-European modernity, it is not difficult for us to see how a Confucian regime would prima facie possess normative legitimacy in this sense, since it would classically satisfy the triadic conditions. Such a regime would have authority inasmuch as the participation of individual actors would be induced by virtue (neither coercion nor persuasion): the Analects characterises a ruler's exemplary virtue as radiating to the people, conducing their obedience and sometimes their own virtue (Analects 2.3, 12.19). It would have religion inasmuch as a participant is related back by its standards and models to the community's founding by the sage kings. And it would have tradition inasmuch as rituals and learning function as standards and models that encode the testimony of those sage kings, as well as later, recognised augmenters of those codes (e.g. Confucius).

Arendt understands a totalitarian regime to not only compromise freedom and normative legitimacy, but in doing so impute an ersatz legitimacy upon itself. ${ }^{7}$ She characterises totalitarianism as

\footnotetext{
6 'Normative' here is meant in terms of the structure of authentic human activity versus substantive morality, which would involve discussion of the content of those norms.

${ }^{7}$ An authoritarian regime uses laws that restrict freedom in restricting the scope of work and action, thus (ironically) losing authority because participation in the regime is not secured by political obligation but the enforcement of such laws. But this does not by itself confer putative legitimacy on the state for complying participants and there still remain spaces of appearances, within which individuals could present themselves to others as distinct individuals.
} 
the "rise of the social" or biological (Arendt 1998, 38), inasmuch as totalitarianism reduces all human activity to the sole dimension of labour by foreclosing--versus merely restricting--the dimensions of work and action entirely. This reduction occurs due to the interrelated elements of terror and ideology, which function to confer putative legitimacy by collapsing action and work into labour--and thus enclosing politics purely within the dimension of the animal laborans.

Terror forecloses action by reducing the human plurality of individuals into a singular conception of 'mankind': as a literal body politic. Rather than a lawlessness such as in the case of tyranny, where 'laws' are subject to the arbitrary will of a single individual, terror is precisely a lawfulness to the laws of History and Nature which "eliminates individuals for the sake of the species" (Arendt 1976, 465). This involves the state identifying its laws with the supposed laws of an unfolding History or Nature, aimed at fabricating humanity as an objective singularity. And unlike authoritarian forms of government, which attempt to stabilise the (quasi-)political community by curbing spontaneous action with positive laws (which, in a way, themselves set up "boundaries and channels of communication between men"), totalitarian 'stabilisation' is carried out by means of eradicating such laws which individuate and connect human beings (Arendt 1976, 465). It functions to relate individuals by de-individuating them as mere specimen, merging human plurality into a single humanity and effacing the space of distinction between human beings.

Ideology forecloses work by necessitating all activity according to a single idea. Where terror realises the state's identification of its laws with the laws of History and Nature, ideology realises the state's identification of the development of an idea with the movement of History and Nature. This development is "the consequence of the 'idea' itself and needs no outside factor to set it into motion," being able to explain every historical and natural event according as the unfolding of its internal logicality (Arendt 1976, 469). This process, which is more primary a concern for a totalitarian state than the 'idea' itself (e.g. Aryanism), is achieved by the application of dialectical logic to every idea, such that each idea "is transformed into a premise" (Arendt 1976, 469). This overlay of ideological framework upon reality results in all entities being understood and experienced as mere resources to be utilised for ends external to them whenever necessary. The connection that human beings might have had to the world, by relating to the world as a human artifice, is mediated (or, rather, interrupted) by the 'reality' of ideology which insists on "a 'truer' reality concealed behind all perceptible things" (Arendt 1976, 470-471). The animal laborans thus contributes to the fabrication process not even as a unique specimen but as a specimen that is dispensable and replaceable, against the background of a normative History and Nature.

A totalitarian regime is thus stabilised by an ersatz legitimacy grounded in terror and ideology rather than freedom: authority does not rely on coercion or persuasion for inducing the participation of its actors, but it instead relies on the natural necessity of the animal laborans (e.g. survival of the Aryan species); religion relates a participant back to a cosmic inauguration of History and Nature by which the disindividuated participant is understood as an undifferentiated specimen of a transhistorical species (e.g. Aryan racial genealogy and their divine lineage); and tradition involves standards and models that encode the 'testimony' of History and Nature (e.g. Nazi racial policy).

The comparison set out here thus concerns whether the Mencian or Xunzian articulations of this triad of authority, religion, and tradition lend themselves to such a totalitarian appropriation in the functioning of terror and ideology. Accordingly, I compare Mencius and Xunzi with respect to their distinct understandings of ren as the grounds of virtue, the relating of a participant of the social order to the sage kings by means of the rituals (leaving aside learning here), and how the standards and models encode the sage kings' testimony and the principles of their augmentation in the rectification of 
names. I evaluate them on the basis of whether their articulations are consistent with a singular understanding of humanity as expressive of a normative History and Nature or grounding motivation for participating in the regime in natural necessity. As such, how ren, rituals, and rectification relate to Mencius and Xunzi's conceptions of human activity par excellence is central to the comparison.

\section{Mencian Naturalism}

Ren, at the core of the Confucian conception of virtue, has two senses. In its first sense, it is an allencompassing normative ideal, which may be translated as 'humanity' (as in 'humaneness'). ${ }^{8}$ In its second sense, it is a single desirable disposition among others constituting one's humanity and located in the heartmind [xin 心], which may be translated as 'compassion'. For Mencius, being human [ren 人] is connected in principle to humaneness in ren. He states that "[h]umaneness is to be human" (7B16) and goes as far as referring to anyone lacking the relevant proto-dispositions (e.g. ceyin 惻隱, which leads to ren) as not being human [feiren 非人], as lacking one's Heaven [tian 天]-endowed humanity (2A6).

This natural-normative conception of humanity is elaborated in Mencius' twofold articulations of it in terms of agriculture metaphors (e.g. four proto-dispositions as the heartmind's 'four sprouts' [siduan 四端]) and also in terms of qi [氣], the 'vital energy' permeating all things, with this concept being resonant with the "'material virtue" traditions" of the time like the medical text Huangdi Neijing (Raphals 2011, 147; cf. Csikszentmihayli 2004). An individual's qi was understood to be in a feedback loop with the heartmind: the heartmind's directedness [ $2 b i$ 志] would determine the flow of $q i$, but were it not directed, it would be buffeted by $q i(2 \mathrm{~A} 2)$. And it on the basis of such a directed flow of $q i$ that normatively appropriate action, i.e. $y i$ [義], may be flexibly achieved in any circumstance (Choi 2019).

Notably, one's $q i$ and pure $q i$ (including the cycles of meteorological and seasonal $q i$ ) are not normatively discontinuous. As Mark Csikszentmihayli argues, Mencius' description of his own qi as “vast, flowing” [haoran 浩然] and "consummately great and consummately strong” in 2A2 is best read in line with early commentators, such as Dong Zhongshu, who understood it as Heavenly qi [tianqi 天氣] (Csikszentmihalyi 2004, 153).9 'Vast, flowing $q$ ' is thus said to "[fill] the space between Heaven and Earth" (2A2), suggesting a natural-normative continuity between the corresponding appropriate activity of one's heartmind and the organic processes of Heaven. In this sense, nourishing and preserving the heartmind [cunxin 存心] to fully develop it may be said to "serve Heaven" (7A1). Human activity par excellence, therefore, aims at preserving the heartmind and nourishing $q i$ because this would accord with one's nature [xing 性]--and such nature is said to be common to the ordinary person and the sage kings who are same in kind [lei 類] (2A6, 6A6-7, 6B2). Mencius would even compare someone who can no longer preserve [cun 存] this to "be at scant remove from the [non-human] animals" (6A8).

\footnotetext{
8 Here, I follow Irene Bloom's (2009) translation of the Mencius and Eric L. Hutton's (2015) translation of the Xunzi, departing only when appropriate. Citations from the Xunzi follow Hutton's divisions by chapter and line.

9 For alternate readings of '浩然之氣', see, e.g., Chan 2002a. Most readings, however, nevertheless converge on there being a normative continuity.
} 
From this, we may see that the authority of a Mencian regime is grounded in a naturalnormative notion of ren characteristic of human activity, according to which individual actors (ruler and ruled, though led by the former) participate in the regime without coercion or persuasion. These participants are also related back to the political community's founding as they cultivate the same qi as the sage kings, since they share the same nature. And rituals encode the sage kings' testimony inasmuch as they facilitate activity that preserves the heartmind and nourishes qi: Mencius observes that the rituals arise from the four sprouts expressing themselves (3A5). The principles of augmenting these rituals are similarly rooted in realizing human potential: in 5A2, Mencius in fact interprets Emperor Shun's violation of ritual order in failing to inform his parents about his marriage by appealing to Shun's violation as an expression of humanity [ren 人] (specifically, the "greatest of human relationships") that trumps ritual demand. ${ }^{10}$ We thus find that a natural-normative conception of human activity plays an important role in legitimising a Mencian regime.

The above reading would not be uncontroversial, turning on how such claims in 2A6 and 7B16 should be interpreted. Bryan Van Norden argues that they are best understood as "generic" rather than speciesist claims, since the latter excludes psychopaths by conceptual fiat (Van Norden 2007, 220-222). Reconceptualising the species to exclude individuals is consistent with totalitarianism, yet what is crucial here is whether the principle grounding these claims can be appropriated by such regimes for their own normative conception of the human species. Speciesist claims, after all, are simply a subset of principled generics, whose subjects' features are grounded in natural kinds (cf. Leslie et al. 2009). That there are bad specimen (e.g. Ox Mountain cases of $6 \mathrm{~A} 8$ or the wild man of 4B28) otherwise indistinguishable from non-specimen would be irrelevant for a regime aimed at perfecting the species.

Another worry is that this is an 'essentialist' reading that smuggles in some notion of an Aristotelian substance, whose essence allegedly provides a natural teleology independent of cooperative action in a social environment (e.g. Ames 2002). Such a conception of teleology, they argue, would be foreign to the "early Chinese thinkers" who did not "[draw] a distinction between essential and accidental properties" (Shun 1997, 7). However, despite these philological concerns, it remains "the tacit assumption of many scholars and translators that human nature in the Mencius denotes an essential property of human beings" (Chan 2002b, 4; see Hansen 2000, Van Norden 2007). This is perhaps partly due to its significance for particular kinds of reconstructive political projects: Roger Ames rightly observes that "the essentialist interpretation promises many of the prerequisites for liberal democracy, certainly notions such as autonomy and equality, which provide a basis for individually conceived political rights" (Ames 2002, 86; cf. Angle 2002). So this reading would provide at least a warning for Confucian reconstructions of liberal democracy intending to avoid totalitarian appropriation not to take Mencian naturalism for granted.

With this, I will now go on to consider how this naturalistic account of Mencius may be appropriated in terror and ideology for a deindividuated conception of humanity and natural political motivation, paying particular attention to the concepts of ren, rituals, and the rectification of names.

\subsection{Terror and Nature}

Mencius' notion of ren may easily be appropriated for terror if we consider the ways in which individuals relate to each other in ren and rituals take place against the background "organismic"

10 This also applies to concerns about learning: as Jane Geaney notes, "for the most part the interpretation of odes in the Mencius also seems fitted to suit the occasion" (Geaney 2011, 138n27). 
processes of Heaven--especially given the 'continuity of being' which, undergirds ancient Chinese assumptions about reality, wherein "all modalities of being are organically connected" (Tu 1989, 67). This continuity becomes salient when we consider the Mencius' portrayal of the ideal social order in terms of a literal body politic and its dispensationalist theory of sage kings. As D. C. Lau argues, Mencius seems to project the relation between the labour of the heartmind and the labour of strength onto the relations between ruler and ruled, providing a strict analogy between the person and the state (Lau 2004a, xviii). ${ }^{11}$ Coupled with the influence on nourishing $q i$ by one's social position (7A36), it would not be inconsistent to understand realising one's humanity to be inextricably embedded in the realisation of the humanity of the body politic itself--if not also extending to all-under-Heaven [tianxia 天下].

And when attending to his dispensationalist theory of sage kings, however, the appropriability of Mencian political philosophy for terror's normative History or Nature becomes even more salient. In $2 \mathrm{~B} 13$ and $7 \mathrm{~B} 38$, Mencius sets out a theory charting the occurrence of sage kings according to quincentennial cycles of Heaven. But this is not merely a historical quirk of some speculative philosophy of history of his time (Nivison 2002). It underscores the possible extent of his naturalistic commitment: just as meteorological and seasonal phenomena are cyclical according to the determinations of Heaven, so is the ren of the body politic cyclical according to the same (specifically that of all-under-Heaven) (cf. 1B14).

A totalitarian state may thus appropriate a discourse of ridding itself of mutilators of humanity--seen as hindrances to the development of the current dispensation of the sage-cycle--to at least justify coercive and deadly force against 'exceptions' as necessary steps (i.e. weeding) towards the realisation of ren. This might be one way to understand the exchange about the regicide of King (Tyrant) Zhou, where Mencius justifies it on the basis that it was not 'regicide' but the "punishment" of a "mutilator" of humanity [zeirenzhe 賊仁者] (Mencius 1B8, trans. Lau). ${ }^{12}$

Furthermore, since ritual originates in, and is subordinate to, ren as we saw in 5A2, ritual order may be seen as an instrument to facilitate the merger of all speech and action in service of the Heavenly narrative--rather than delineating boundaries between the zoon logon ekhon with their own narratives--and as such function to foreclose the phenomenological dimension of action.

\subsection{Ideology and Nature}

That human activity is normatively undergirded by an organic urge to manifest the same natural potential allows for motivating participation in a totalitarian regime on the basis of the animal laborans' activity. What is required is a kind of hermeneutical overlay over (or, rather, undermining of) reality required for ideology. It is here that attending to the rectification of names, alongside our considerations thus far, would be instructive in seeing how the natural-normativity in the Mencius can be appropriated to foreclose the phenomenological dimension of work, since crucial to nourishing flood-like qi is "understand[ing] words" (2A2)--and, as Tan Sor-Hoon observes, "'to name' is closely associated with 'to command, to bring into existence'." (Tan 2004, 179).

\footnotetext{
11 The Spring and Autumn Annals explicitly conceptualises communication between ruler and ruled in terms of body's flow of $q i$, which we have noted to be normatively continuous with the qi-at-large (Nylan 2008, 91).

12 This totalitarian reading is contrary to how $1 \mathrm{~B} 8$ is commonly interpreted, which takes Mencius' justification to be based on King Zhou having taken the non-ren course that leads to regicide because it incurred the people's reprobation (4A2, cf. 5A5). E.g. Bloom translates '賊仁者' as 'brigand'.
} 
The rectification of names is crucial to the political project of Confucianism more broadly, which may be seen as applying its conception of government-as-rectification to the domain of language (Analects 12.17). Specifically, the rectification of names involves the idea that "[a]n incorrect mode of speaking and naming is a direct cause of sociopolitical and ritual disorder" (Loy 2008, 235). And while there is no explicit reference to the rectification of names in the Mencius (it is more often associated with the Analects 13.3 and the Xun₹ ), we nevertheless see Mencius expressing a similar concern for rectifying the heartminds of people [₹hengrenxin 正人心] by means of disputation [bian 辩] (3B9). There are also arguably outright instances of him rectifying names (Loy 2020): the discussion with Gaozi in 6A3-4 are resonant with the Neo-Mohist "dialectical chapters" (Van Norden 2007, 88; cf. Lau 2004b) and, as we saw earlier with 1B8, Mencius rectifies King Xuan's use of the term 'ruler' [jun 君], when referring to the regicide of the tyrant Zhou. Mencius also specifically distinguishes between "ritual" and "true ritual" according to whether a great person practises them (4B6, emphasis added), no doubt as part of ensuring that words "correspond to reality" and, further, not "obscure the reputation of a person of ability" (4B17). Such rectifying disputation is rooted in an understanding of language as a natural tallying between names [ming 名] and objects in the world: a word designating a thing ('horse' for a horse) is a foundational semantic unit (cf. Fraser 2013).

But although such rectification does not on its own imply a "linguistic totalitarianism" in prescribing what one can say, it may nevertheless, coupled with natural-normative motivations, lend itself to totalitarian appropriation for securing a 'natural' description of the underlying reality of things, since the rectification of names is "a matter of transforming a discourse or practice from within, by working on the connections between one's words and actions and thereby influencing how others connect them" (Tan 2004, 179). In the rectification of names, ways of speaking and acting (of beingin-the-world) would be circumscribed by one's natural-normative position within the social order.

Motivating the realisation of the organismic process of humanity would require mediating and severing human beings' creative capacity and direct, unique relation to the world as homo faber: the rectification of names would allow the totalitarian regime to do this by foreclosing deviant and destabilizing ways of being-in-the-world. After all, nourishing qi requires weeding the heartmind's seedlings, which is to rid one's language of "distorted," "licentious," "deviant," and "evasive" words (2A2). As such, the rectification of names would be able to provide "the most reliable of all safeguards against the words and the presence of others, and hence against reality as such" (Arendt 2006, 48-49), constituting the means whereby ideology might naturalise every experience within itself, with such naturalization leaving human beings unable to understand themselves apart from an animal laborans which has its "metabolism with nature" and thus precluded from cultivating the other dimensions of human activity (Arendt 1976, 475).

To sum, it is neither inconsistent nor difficult for a totalitarian regime to appropriate Mencian political philosophy insofar as it wants to stabilise itself with an ersatz legitimacy facilitated by a naturalistic commitment to human activity: for, under a Mencian totalitarian regime, authority, religion, and tradition all normatively bottom out in the organismic processes of Heaven.

\section{Xunzian Constructivism}

At the heart of the Daoist critiques of Confucianism (especially the Zhuangziss) are critiques of a naturalistic enframing of human activities as organic processes. So if Confucianism is to avoid the above charge of being susceptible to totalitarian appropriation, one option would be to turn to a 
version of it which takes into account these critiques and offers a way to reconceptualise political legitimacy non-naturalistically. One such version is the constructivist Confucianism of the Xunzi (although I will also briefly gesture to a non-naturalistic Mencian reading later).

To clarify, the opposition between naturalism and constructivism set up here, pertaining to phenomenological concerns, is only tangentially related to an existing debate between ethical 'constructivist' and 'realist' readings of the Xunzi (see Hagen 2007 and Hutton 2007). ${ }^{13}$ These readings pertain largely to the Dao's metaethical status and its content, but that the Xunzi allows for the multiple realisability of social institutions is distinct from the question of whether the text implies only one (Confucian) ideal way for them to be organised. ${ }^{14}$ And even those in 'realist' camps are in agreement that human beings participate in some ways to create multiply realisable institutions that can embody the Dao in a singular way (e.g. Ivanhoe 1999, Hutton 2007).

What is crucial here, rather, is that, while we saw Mencian Confucianism regarding Heaven to be normatively continuous with humanity, Xunzi makes a clear distinction between the natural realm and the human realm: the normativity of human activity is not continuous (although nonetheless contiguous) with the operations of natural processes. Left on their own, these operations do not conduce human activity above mere survival as animal laborans: this discontinuity is the reason for the flourishing of human beings against the natural threat of predatory non-human animals (Xun₹i 9.329, cf. 9.274).

The constancies of Heaven are indifferent to human activities, and ethics and politics are fundamentally human affairs for which the facultative endowments of Heaven are insufficient (Xun₹i 17.1-33; see Cheng 2014). Unlike Mencius, Xunzi does not identify being human with natural dispositions and $q i$ no longer has normative significance. ${ }^{15}$ The locus of dispositions is not the heartmind but the five facultative endowments [wnguan 五官]. Characteristic human activity is, rather, grounded in the heartmind's making of distinctions [bian 辨] in response to the provisions of the faculties (Xun₹i 5.104-115, reading 辨 as an activity). While non-human animals have distinctions (e.g. reproductive or sex-based), they do not make them. ${ }^{16}$

Notably, it is not mere possession of the capacity of distinction-making whereby we are considered human, because the heartmind itself is a Heavenly endowment (Xun₹i 17.57-58). Characteristic human activity emerges from the exercise of our capacity for making distinctions. This is realised in deliberate effort [wei 偽], wherein "the [heartmind] reflects and one's abilities act on" a certain disposition (Xunæi 22.16; cf. Lee 2005). That is, characteristically human activities involve the

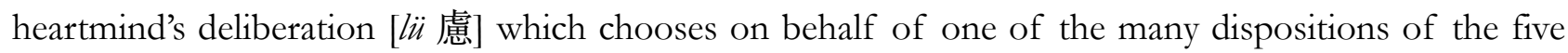
faculties. Such a choice is based on how different forms, encountered by the five faculties, "are understood as different things" when they "make contact with the [heartmind]," which then makes shil $f e i$ [是/非] distinctions to mark differences between things perceived (Xun₹i 22.59-60). That something is $(s h i)$ or is not $(f e r)$, is whether there is a said object--extending to designations of whether something

\footnotetext{
13 'Constructivism' here comes closer to social construction theories, broadly construed (e.g. Haslanger 2012).

14 For those favouring ethical constructivist interpretations, see, e.g., Hagen 2007 and Tan 2015. Conversely, see Ivanhoe 1991 and Van Norden 2000.

15 See Stalnaker 2006 for a discussion on Xunzi's take on qi.

16 Non-human animals "have awareness [知]", which even allows them to love their own kind [lei 類] (Xunzi 19.469), but this is merely a matter of receiving phenomenal input from the faculties (Xunzi 22.93-94).
} 
is desirable or not (Xunzi 22.88-100). And this not unique to the virtuous: the vile person [jianren 姦人] is also said to deliberate (Xunzi 4.130-135).

According to Xunzi, the deliberations and distinctions that are made by human beings are intimately tied to, and created based on, a deep understanding of the natural world. In "Discourse on Heaven," he repeatedly emphasises the need to be sensitive to the triadic cosmological arrangement of Heaven, Earth [di 地], and humankind, and thus acting in a way that accords due diligence to each element--this being fundamental to how human activity should be carried out (Xunzi 17.1-39; cf. Bethrong 2016). Distinction-making should not involve deliberation on, but rather be appropriately responsive to, meteorological and terrestrial contingencies (their regularities and irregularities), since these are not affected by deliberate effort. Xunzi thus explicitly criticises Mencius as confusing what is "nature," which "cannot be learned and cannot be worked at," with what is "deliberate effort," which can be learned and worked at (Xun₹i 23.50-55).

Further, Xunzi distinguishes between two targets of distinction-making: distinctions that pertain to non-human objects and distinctions that pertain to human beings, i.e. "social divisions" (or 'allotment') [fen 分]. And these distinctions, in turn, are expressed in two different kinds of activity [wei 為]: work [shi 事] and practice [xing 行] (Xun₹i 22.18-20). In work [shi 事], which distinguishes between non-human objects and animals, human beings act for the sake of profit. And in practice, which distinguishes between the human activity of work [shi 事], human beings form communities (Xunzi 9.323-324). Without communities and their corollary social divisions, work that lacks communal organization would naturally result in chaos.

Again, the two targets of distinction-making, along with their respective spheres of activity, are not unique to the virtuous. As Eirik Harris astutely observes, for Xunzi, human beings "can selfconsciously form community based on [social] divisions" even before they "self-consciously form community that takes $y i$ [義] as the basis for its [social] divisions” (Harris 2016, 103). The hegemon [ba 霸] is already able to makes social divisions out of “concern for the people [aimin 愛民]," expressed in "heavy laws [zhongfa 重法]” (Xunzi 17.200-201). But what distinguishes a community of a hegemon and that of a true king [wang 王] is that the former obtains participation by coercion and persuasion, while the latter enjoins participation by "virtuous reputation” (Xunzi 10.149; Harris 2016, 130).

As a Confucian, Xunzi's political ideal is still a ruler who makes social divisions out of ren [仁], expressed in ritual--where 'ren' means a “care [ai 愛] for others” corresponding to $y i$ as appropriate channels of care and 'ritual' means the appropriate models [fa 法] whereby $y i$ is expressed and according to which people are socially divided (Xunzi 27.104-131). However, the key departure from Mencius is that, for Xunzi, the system of rituals and $y i$ were established by the sage kings, providing social divisions in response to the chaos of unorganised work [shi 事] among the people, rather than arising continuously from any one's own dispositions as we saw with Mencius (Xunzi 19.7-9). And it is this established system of ritual and $y i$ that has normative significance as the Dao. ${ }^{17}$

\footnotetext{
17 This is still compatible with either side of the ethical realist or constructivist debate: the Dao still may or may not be multiply realisable. What matters for us here is only whether its normativity is secured by a continuity with the operations of natural processes--which it is not.
} 
From this, we can see that the authority of a Xunzian regime is grounded in a constructivist notion of ren that is not characteristic of human activity per se but instead minimally involves a care for others along the lines of mutual profit, according to which individual actors are drawn participate in the regime without coercion or persuasion. ${ }^{18}$ These participants are also related back to the political community's founding insofar as they act in accordance with the rituals and $y i$ that were constructed by the sage kings--which thus also encodes their testimony. The principles of augmenting (the content of) these rituals, which provide social divisions, would thus be rooted in appropriate responsiveness to the circumstances of Heaven and Earth, since the ideal ruler fixates on neither "the ancient past" nor "the present" and his "policies adapt to changes endlessly" (Xun₹i 9.219, 21.140-141; cf. Hagen 2003). We thus find that a constructivist conception of human activity plays an important role in legitimising a Xunzian regime, for unlike a Mencian regime, there is a clear normative distinction between the human [ren 人] and humanity [ren 仁].

I will now go on to consider how this, unlike the Mencian conception of humanity, would not be able to be similarly exploited for appropriation in terror and ideology, paying particular attention to how the concepts of ren, rituals, and the rectification of names would undermine a deindividuated conception of humanity and natural political motivation.

\subsection{Terror and Constructions}

What might seem worrying at first glance is that in the "Discourse on Heaven," Xunzi describes the heartmind as one's "Heavenly ruler" and the five faculties to be one's "Heavenly offices" (Xunzi 17.5059), bringing to the fore an explicit image of a body politic, similar to what we have seen with Mencius. Furthermore, the scope of the true king's ren is meant to encompass all people under Heaven (Xunzi 9.202-205, 12.75-76). In this community, a combination of work and practice would allow human beings to "Overcome" non-human animals (Xunzi 5.113, 9.274-339). Yet, there are also numerous instances wherein Xunzi seems willing to compare deviant actors, those lacking ren, to non-human animals (e.g. Xun₹i 1.135, 2.16-17, 13.189)--or seemingly going further in his dehumanization to regard those who disregard ritual as even less than that (Xun₹i 19.481-2). It would therefore seem prima facie quite consistent for Xunzi's promotion of the proper order of humankind, the third element of the cosmological triad, to be appropriated in terror.

Yet, firstly, Xunzi's analogy between the state and the body is not a return to a naturalnormative continuity. In fact, Xunzi's aim in using them in this passage is precisely to use the discourse of his interlocutors, who employed the discourse of "[keeping] whole the accomplishment of Heaven" to rely on natural processes, against themselves (Xunzi 17.69-70). If keeping the accomplishment of Heaven matters to his interlocutors, they would do well to go beyond natural processes for guidance on how to do so. He explicitly notes that "[t]hat which is accomplished without anyone's doing it and which is obtained without anyone's seeking [...] is called the work of Heaven": and one should not "[compete] with Heaven's work" (Xunzi 17.27-34). Xunzi goes as far as to attribute the loss of the accomplishments of Heaven to a person not knowing the limits of "what he is to do and he is not to do" (Xunzi 17.70-71). It is such ignorance that would result in socio-economic disorder, thus eventually affecting the person himself too--which Xunzi emphasises as not being due to Heaven or Earth. Therefore, he is removing normativity from that which are to be naturally found in being human. 18 Many note that Xunzi's concerns goes beyond just consequentialist ones, involving an irreducible aesthetic dimension
(e.g. Harris 2016, Loy 2016). 
Secondly, in a more sober occasion, Xunzi laments that though he would "classify [brawlers] as birds, rodents, or beasts," he cannot "because their form is nevertheless human, and their likes and dislikes are mostly the same as those of humans" (4.57-59). Xunzi's comparisons to non-human animals may thus be best understood hyperbolically, as part of the "difficulties of persuasion": the need to "[shift] with the occasions and [bend] with the times," to "raise remote parallels without being misunderstood, and cites closer events without being crude," as the gentleman's "method of inclusiveness" when dealing in others (Xunzi 5.193-213). Attending to his comparison of someone as being less-than-animal, we find that this is because a bypothetical [ruo 若] person who acts in such a way would not demonstrate possession of awareness, which even non-human animals have.

More importantly for us, this would also be inconsistent with the constructivist account laid out above: terror requires a singular conception of mankind that deindividuates participants in a regime, but ren is precisely caring for others according to the social divisions of $y i$ which are multiply realisable, contingent on meteorological and terrestrial factors (which is not to say that rituals and yi are themselves multiply realisable; cf. Hagen 2003). The rituals set up social distinctions (including statuses, duties, and responsibilities) to prevent the world's 'bemuddlement', which creates "great chaos," by restricting the overstepping of action and speech among people (17.242-243). Social divisions thus circumscribe space for speech and action, and such a space could be understood to allow actors to disclose themselves to others as a 'who' and not merely as part of a body politic.

However, this would only prevent the foreclosure of action and would not suffice for disclosing it. It is crucial to note here that Xunzi's two spheres of activities, of work [shi 事] and practice, still only fall under the Arendtian notion of work and not yet her notion of action, since social divisions are made not on the basis of harmonizing self-presentations but on the basis of harmonizing desire. What is needed is an organisation of social relations which supervenes on the shared, created world of named objects, yet not in such a way that determines the relations between human beings. Yet I think that we can take this constructivist position further for this in a way that was not possible with a naturalistic conception of interrelationality.

One way to approach this would be to consider how there can be space for any disclosure of the individual in ritual practice if rituals are the taking of the actions of sage-kings as models [ $\mathrm{fa}$ 法]. As Antonio S. Cua suggests, it is not inconsistent to understand the term 'sage-kings' as titles retrospectively attributed to those who had established the rituals whereby social order is achieved--rather than the titles preceding the establishment of the appropriate rituals (Cua 2000; cf. Lau 2000). This might be gleaned from Xunzi's description of the sage-kings as those who have crossed waters, "[marking] out the deep places" (Xun₹i 17.238-240). Further, Xunzi emphatically does not take the rituals to fully encode the Dao and explicitly advocates the need to adapt rituals in response to changing material circumstances (Xunzi 9.219, 21.140-141; cf. Analects 9.3, Hagen 2003). Still, what is necessary for action is conceptual room for rituals to be adapted in response to changing social circumstances and not for the sake of profit.

This can be drawn out of the Xun₹i. We can distinguish between two obvious ways of 'making distinctions': the creation of distinctions (as the sage kings did) and the use of distinctions (as the common people do). But Xunzi also gestures towards a gradation of use, between those who understand the rituals and those who simply carry them out "as set customs" (Xunqi 19.567-570). Moreover, as we saw earlier, Xunzi compares the conduct of petty men to non-human animals, insofar as they act only according to natural dispositions and merely have distinctions (e.g. reproductive). Still, this does not mean an identification between the two, since non-human animals are not deliberative. 
From these, it could be thus said that we use distinctions actively when we deliberatively agree upon them based on other distinctions, versus passively, when we simply take them as given.

What the active-passive distinction allows is the possibility of a community of distinctioncreators and active distinction-users (which need not be mutually exclusive in social practice), who are able to make themselves as measures in relating to each other (Xunæi 5.148) such that one's creation of social divisions not only take into account the contingencies of oneself and others, but also the creation of social divisions by others. The zoon logon ekhon may thus disclose themselves as a 'who' in the space of this interplay between the creation and use of social divisions. Moreover, what would be ultimately encoded by ritual can thus be understood as neither an irreducibly subjective action which excludes imitation, given its particularities, nor an objective fixation on a corner of the Dao's myriad dynamism. Rather, rituals would be understood as an intersubjective negotiation of pragmatic considerations among distinction-creators-users, equilibrating over time to become stable and stabilising distinctions in specific, but an extensive number of, social contexts (cf. Wilson 2018).

\subsection{Ideology and Constructions}

Similarly, a Xunzian rectification of names both is resistant to totalitarian appropriation and harbours the possibility of anti-totalitarian disclosure.

"On the Rectification of Names" contains the most explicit exploration of the titular notion in the classical Confucian canon, and one might expect this to better facilitate ideology's hermeneutical overlay of reality. And Xunzi seems to be just as hostile to those whose "arguments are niggling and without unifying order," regarding them as “the vile person's hero [jianrenæhixiong 姦人之雄]” who "cannot be changed" and would be the first to be executed under the regime of a sage king (5.260270).

In sharp contrast to the naturalness of names in a Mencian naturalism, Xunzi's understanding of the rectification of names begins with the crucial premise that names "have no predetermined appropriateness" (Xunzi 22.123-124). Naming, importantly, neither precedes nor determines the distinctions differentiated by the heartmind among the forms which are encountered by the five faculties (Xunzi 22.58-87): names have no necessary, natural connection with the objects designated. Rather, naming forms is a post hoc exercise that isolates the particular forms encountered, making it possible for us to refer to them as things and compare their similarities with varying levels of specificities and generalities (Xunzi 22.88-139). Further, naming confers a 'thingly' permanence (though limited) upon otherwise impermanent forms. Only the distinct forms that have been named, agreed upon and "have become custom," are 'brought into existence' as distinct objects in practice-distinctions, as in differentiated objects, can thus be said to be created (Xun₹i 22.125-126).

Yet Xunzi nevertheless regards some names to be bad and to bring about disorder, and advocates that one's naming should follow the Dao as the "warp and pattern of good order" (Xunzi 22.189). But the reason for them being bad or bringing about disorder is not a matter of natural necessity. The "predetermined goodness" of names are purely a formal matter: "if they are straightforward, simple, and do not conflict, then they are called good names" (Xunzi 22.126-127). So to rectify names would be to ensure that there is not a reckless creation of names, such that there is not a "making up strange names so as to disorder the correct names" (Xunzi 22.37-38). Further, as the Dao was established by the sage kings, in aiming at mutual benefit, the creation and use of names arise out of pragmatic concerns: there is a need to "procure agreement" for names for successful communication, 
intentions to be understood, and collective projects not to fail (Xun₹i 22.192). This is how distinctions are social without yet being social divisions. And should the material conditions change such that our five faculties receive different forms, the capacity to create distinctions allows "a true king" to respond accordingly by bringing forward new names, and thus objects, where appropriate to replace old ones (Xunzi 22.53-55). The objects that we find constituting the world of our activities do not thereby exhaust the possible objects that could exist, allowing for creative freedom in work. From this, we can see that the contingency acknowledged by such constructivism to underlie the rectification of names-located in both the forms encountered and the social creation of the objects themselves--would be inconsistent with attempts by a totalitarian regime to appropriate the concept in ideology.

Moreover, creative freedom is not necessarily reserved for the true king. We can appeal to the same kind of interplay in ritual, as involving the creation and active use of social divisions in action, with the creation and active use of names in work. And, more clearly than in action, it is possible for the Xunzian rectification of names to have a participatory equilibrium in this interplay, wherein "the people and the government" are "coparticipants" (Tan 2004, 180-181; cf. Hagen 2002). Unlike a hegemonic state, such a Xunzian regime would not have names "imposed top-down unilaterally": "the interactions that modify and are modified by those [names] in need of adjustment" may be directed, but not determined, by the Xunzian state (Tan 2004, 181). As such, the division between the natural and the human world--the gap of creative freedom foreclosed in ideology--would be itself disclosed in the activity of naming that Xunzi explicitly recognises everyone as capable of.

Correct names are those that secure the stability of our activities in the shared world--and thus the stability of the shared world as such. So the rectification of names would thus be a constitutive activity of the homo faber under a Xunzian regime, wherein distinctively human objects, having been mediated by the heartmind, are brought into a shared world of permanence. This shared world then mediates and secures meaning for the activities of human beings, who would otherwise be reduced to animal laborans alienated from each other, and a stable world outside of Nature's processes.

To sum, the twin elements of terror and ideology of the totalitarian state are less consistent with, and even meet resistance from, a constructivist version of Confucianism. The concepts of ren, rituals, and rectification contain within themselves inherent contingencies--which cannot be appropriable for the 'natural' and naturalizing necessity of totalitarianism. We can also further see that the constitutive activities of the vita activa may have the possibility of disclosure where it would be foreclosed under a naturalistic version of Confucianism.

As mentioned, there are non-naturalistic approaches to the Mencius, the most prominent being Ames' process account. According to this, human activity par excellence would be a matter of "social achievement": ren would be fundamentally a social rather than biological capacity, with rituals and rectification as matters of participatory construction (Ames 2002, 85). Others have attempted to maintain a biological base for a common humanity [ren 人] shared by human beings, while simultaneously resisting natural teleology (e.g. Bloom 2002, Perkins 2011). These accounts might be able to resist totalitarian appropriation in a similar way to the Xunzian account set out here, and their relation to totalitarianism warrant further attention.

\section{Conclusion}

I have argued that charges against Confucianism being appropriable for totalitarianism can be understood to be justifiably directed at a naturalistic, Mencian version versus a constructivist, Xunzian 
version. I have also considered how the constructivist version might harbour the possibility of resistance against totalitarianism.

The problematic here is admittedly framed by a contemporary Anglo-European paradigm, but it is nevertheless crucial for its related schools theorising about politics to ask whether Confucianism (and its recent reconstructions) can at least assuage their originary worry. I submit that, against the relative decline in interest in totalitarianism within the current fields of Anglo-European political philosophy (barring a few exceptions e.g. Caplan 2012), the possibility of justifying such regimes is still a pertinent one today. This is so at least within the plethora of ongoing discussions among political philosophers (in the anglophone and sinophone world) who are trying to assess the compatibility of Confucianism with democracy. Perhaps as a result of recent Confucian reconstructions drawing more heavily from the Mencius than the Xun₹i, we might see a number of them open to the danger of totalitarian appropriation. At the very least, it is hoped that another approach has been offered here for assessing the relevance of Confucianism to contemporary Anglo-European political philosophy: perhaps not in terms of common goals, but at least common enemies. 


\section{References}

Ames, Roger T. 2002. "Mencius and a Process Notion of Human Nature." In Mencius: Contexts and Interpretations, edited by Alan K. L. Chan, 72-90. Honolulu: University of Hawai'i Press.

Angle, Stephen C. 2002. Human Rights and Chinese Thought: A Cross-Cultural Inquiry. Cambridge: Cambridge University Press.

Arendt, Hannah. 1968. "What Is Authority?”' In Between Past and Future: Eight Exercises in Political Thought, 91-141. New York: The Viking Press.

----. 1976. The Origins of Totalitarianism, Second Edition. New York: Harcourt, Inc.

---- 1998. The Human Condition, Second Edition. Chicago and London: The University of Chicago Press.

----. 2006. Eichmann in Jerusalem: A Report on the Banality of Evil. London: Penguin Books.

Bai, Tongdong. 2014. "Early Confucian Political Philosophy and Its Contemporary Relevance," In Dao Companion to Classical Confucian Philosophy, edited by Vincent Shen, 335-361. Dordrecht: Springer.

Baehr, Peter. 2010. "China the Anomaly: Hannah Arendt, Totalitarianism, and the Maoist Regime." European Journal of Political Theory 9(3): 267-286.

Bell, Daniel A. 2015. The China Model: Political Meritocracy and the Limits of Democracy. Princeton and Oxford: Princeton University Press.

Bethrong, John H. 2016. "Religion in the Xunzi: What Does Tian 天 Have to Do with It?" In Dao Companion to the Philosophy of Xun₹i, edited by Eric L. Hutton, 323-351. Dordrecht: Springer.

Bloom, Irene. 2002. "Biology and Culture in the Mencian View of Human Nature." In Mencius: Contexts and Interpretations, edited by Alan K. L. Chan, 91-102. Honolulu: University of Hawai' i Press.

---. trans. 2009. Mencius. New York: Columbia University Press.

Caplan, Bryan. 2012. “The Totalitarian Threat," in Global Catastrophic Risks, edited by Nick Bostrom and Milan M. Cirkovic, 504-519. Oxford: Oxford University Press.

Chan, Alan K. L. 2002a. "A Matter of Taste Qi (Vital Energy) and the Tending of the Heart (Xin) in Mencius 2A2." In Mencius: Contexts and Interpretations, edited by Alan K. L. Chan, 42-71. Honolulu: University of Hawai'i Press.

----. 2002b. Introduction to Mencius: Contexts and Interpretations, edited by Alan K. L. Chan, 1-16. Honolulu: University of Hawai'i Press.

Chan, Joseph. 2014. Confucian Perfectionism: A Political Philosophy for Modern Times. Princeton and Oxford: Princeton University Press.

Chen, Jie and Peng Deng. 1995. China Since the Cultural Revolution: From Totalitarianism to Authoritarianism. Westport, Connecticut and London: Praeger.

Cheng, Chung-ying. 2014. "Xunzi as a Systematic Philosopher: Toward Organic Unity of Nature, Mind, and Reason." In Dao Companion to Classical Confucian Philosophy, edited by Vincent Shen, 179_ 199. Dordrecht: Springer.

Choi, Dobin. 2019. "Mengzi's Maxim for Righteousness in Mengzi 2A2." Dao: A Journal of Comparative Philosopby 19(3):371-391.

Csikszentmihayli, Mark. 2004. Material Virtue: Ethics and the Body in Early China. Leiden and Boston: Brill.

Cua, Antonio S. 2000. "Ethical Uses of the Past in Early Confucianism: The Case of Xunzi." In Virtue, Nature, and Moral Agency in the Xunzi, edited by T. C. Kline III and Philip J. Ivanhoe, 39-68. Indianapolis / Cambridge: Hackett.

Geaney, Jane. 2011. "The Sounds of Zhèngming: Setting Names Straight in Early Chinese Texts." In Ethics in Early China: An Anthology, edited by Chris Fraser, Dan Robins, Timothy O'Leary, 125-141. Hong Kong: Hong Kong University Press.

Golomb, Jacob and Robert S. Wistrich, eds. 2002. Nietzsche, Godfather of Fascism?: On the Uses and Abuses of a Philosophy. Princeton and Oxford: Princeton University Press.

Guo, Sujian. 2013. Chinese Politics and Government: Power, Ideology, and Organization. London and New York: Routledge.

Hagen, Kurtis. 2002. "Xunzi’s Use of Zhengming: Naming as a Constructive Project." Asian Philosophy 12(1): $35-51$.

----. 2003. "Xunzi and the Nature of Confucian Ritual." Journal of the American Academy of Religion 71(2): $371-403$. 
---. 2007. The Philosophy of Xunzi: A Reconstruction. La Salle: Open Court.

Hansen, Chad. 2000. A Daoist Theory of Chinese Thought. New York: Oxford University Press.

Harris, Eirik Lang. 2016. "Xunzi's Political Philosophy." In Dao Companion to the Philosophy of Xunzi, edited by Eric L. Hutton, 95-138. Springer: Dordrecht.

Haslanger, Sally. 2012. Resisting Reality: Social Construction and Social Critique. New York: Oxford University Press.

Huang, Chun-chieh. 2001. Mencian Hermeneutics: A History of Interpretations in China. New Brunswick and London: Transaction Publishers.

Hutton, Eric L. 2007. Review of The Philosophy of Xunzi: A Reconstruction, by Kurtis Hagen. Dao: $A$ Journal of Comparative Philosophy 6(4):417-421.

----., trans. 2015. Xunzi: The Complete Text. Princeton and Oxford: Princeton University Press.

Ivanhoe, Philip J. 1991. "A Happy Symmetry: Xunzi's Ethical Thought." Journal of the American Academy of Religion 59(2): 309-322.

Lau, D. C., trans. 1979. The Analects. London: Penguin Books.

---. 2000. "Theories of Human Nature in Mencius and Xunzi." In Virtue, Nature, and Moral Agency in the Xunzi, edited by T. C. Kline III and Philip J. Ivanhoe, 188-219. Indianapolis: Hackett Publishing Company.

----. 2004a. Introduction to Mencius, vii-xlviii. London: Penguin Books.

----, trans. 2004b. Mencius. London: Penguin Books.

---- and Chen Fong Ching, eds. 1995. A Concordance to the Mengzi. Hong Kong: Commercial Press.

---- and Chen Fong Ching, eds. 1996. A Concordance to the Xunzi. Hong Kong: Commercial Press.

Lee, Janghee. 2005. Xunzi and Early Chinese Naturalism. Albany: State University of New York Press.

Leslie, Sarah-Jane, Sangeet Khemlani, Sandeep Prasada and Sam Glucksberg. 2009. "Conceptual and Linguistic Distinctions between Singular and Plural Generics." Proceedings of the 31st Annual Cognitive Science Society. Amsterdam: Cognitive Science Society.

Loy, Hui-chieh. 2008. "Analects 13.3 and the Doctrine of 'Correcting Names'." In Confucius Now: Contemporary Encounters with the Analects, edited by David Jones, 223-242. Chicago: Open Court.

---- 2016. "Xunzi Contra Mozi." In Dao Companion to the Philosophy of Xunzi, edited by Eric L. Hutton, 353-375. Springer: Dordrecht.

----. 2020. "Correcting Names in Early Confucianism." In Dao Companion to Chinese Philosopby of Logic, edited by Yiu-ming Fung. Springer: Dordrecht.

Nivison, David S. 2002. "Mengzi as Philosopher of History." In Mencius: Contexts and Interpretations, edited by Alan K. L. Chan, 282-304. Honolulu: University of Hawaici Press.

Nylan, Michael. 2008. "Boundaries of the Body and Body Politic in Early Confucian Thought" In Confucian Political Ethics, edited by Daniel A. Bell, 85-110.

Perkins, Franklin. 2011. "No Need for Hemlock: Mencius's Defense of Tradition." In Ethics in Early China: An Anthology, edited by Chris Fraser, Dan Robins, Timothy O'Leary, 65-81. Hong Kong: Hong Kong University Press.

Raphals, Lisa. 2011. "Embodied Virtue, Self-Cultivation, and Ethics." In Ethics in Early China: An Anthology, edited by Chris Fraser, Dan Robins, Timothy O'Leary, 143-157. Hong Kong: Hong Kong University Press.

Rawls, John. 1996. Political Liberalism. New York: Columbia University Press.

Shun, Kwong-loi. 1997. "Mencius on Jen-hsing." Philosopby East and West 47(1): 1-20.

Stalnaker, Aaron. 2006. Overcoming Our Evil: Human Nature and Spiritual Exercises in Xunzi and Augustine. Washington, D. C.: Georgetown University Press.

---. 2015. "Xunzi's Moral Analysis of War and Some of Its Contemporary Implications." In Chinese Just War Ethics: Origin, Development, and Dissent, edited by Ping-cheung Lo and Sumner B. Twiss, 135-152. London: Routledge.

Sondrol, Paul C. 1991. "Totalitarian and Authoritarian Dictators: A Comparison of Fidel Castro and Alfredo Stroessner." Journal of Latin American Studies 23(3): 599-620.

Tan, Sor-hoon. 2004. Confucian Democracy: A Deweyan Reconstruction. Albany, NY: State University of New York Press.

---. 2010. “Authoritative Master Kong (Confucius) in An Authoritarian Age.” Dao 9(2): 137-149. 
----. 2015. 'Xunzi and Naturalistic Ethics.” Journal of Value Inquiry 49(1): 247-265.

Tao, Jiang. 2006. "Intimate Authority: The Rule of Ritual in Classical Confucian Political Discourse." In Confucian Cultures of Authority, edited by Peter D. Hershock and Roger T. Ames, 21-48. Albany, NY: State University of New York Press.

Thiele, Leslie Paul. 2009. "The Ontology of Action: Arendt and the Role of Narrative." Theory and Event 12(4). doi:10.1353/tae.0.0101.

Tu, Wei-Ming. 1989. "The Continuity of Being: Chinese Visions of Nature." In Nature in Asian Traditions of Thought, edited by J. Baird Callicott and Roger T. Ames, 67-78. Albany, NY: State University of New York Press.

Van Norden, Bryan W. 2000. "Mengzi and Xunzi: Two Views of Human Agency." In Virtue, Nature and Agency in the Xunzi, edited by T. C. Kline III and Philip J. Ivanhoe, 103-134. Indianapolis, IN: Hackett Publishing Company.

---. 2007. Virtue Ethics and Consequentialism in Early Chinese Philosophy. New York: Cambridge University Press.

Wilson, Lee. 2018. "Virtue and Virtuosity: Xunzi and Aristotle on the Role of Art in Ethical Cultivation." Journal of Confucian Philosopby and Culture 30: 75-103. 